\title{
Examination of Structural and Dynamic Properties for Vertical Axis Wind Turbine Blade Made of Stainless Steel using Ansys \\ M.Saravanan
}

\begin{abstract}
This paper studies the potential for installing savonius type Vertical Axis Wind Turbine systems with the goal of maximizing the efficiency and reducing the cost. The wind turbine efficiency depends on the material of the blade, angle of the blade and shape of the blade. So material of the wind turbine blade plays an important role in the design of wind turbine. In this paper, Stainless Steel is used to design savonius wind blades of $1 \mathrm{~m}$ height and $0.5 \mathrm{~m}$ chord length with 4 different arc radii. For this purpose, CAD modeling software Solid Works is used to model savonius wind blade and static structural and modal analysis of the Stainless Steel blade is done by using ANSYS Workbench software. Static structural analysis is used to determine stress, strain, deformation and displacement under static loading condition. The response of structure for dynamic loading is determined by modal analysis. It is used to determine the natural frequency and mode shape of vibration of any structure. This wind turbine is suitable to install in small houses in urban areas.
\end{abstract}

Key Words: Solid Works, Stainless Steel, ANSYS, Structural Analysis, Modal Analysis.

\section{INTRODUCTION}

Savonius wind turbine is one type of vertical axis wind turbine used for converting the wind force into torque on a rotating shaft and electric power. The turbine consists of a number of blades vertically mounted on a rotating shaft. It is low cost and reliable, but efficiency is poor. This turbine is self starting and no pointing mechanism is required to allow for shifting wind direction. Sigurd Johannes Savonius invented this wind turbine in 1922. It was not widely used for many years. Its popularity is increasing recently due to increase of urbanized areas, which have specific demands. The Savonius rotor blade seems to satisfy these particular needs.

\section{DESIGN CALCULATION}

The relationships between wind power, swept area, air density and wind speed are given by below equation [Asis Sarkar 2012].

$$
P_{\mathrm{w}}=1 / 2 \rho A V^{3}
$$

Where $\mathrm{P}_{\mathrm{w}=}$ Power of the wind $(\mathrm{W})$

$$
\rho \quad=\text { Air density }=1.23 \mathrm{~kg} / \mathrm{m}^{3}
$$

\section{Revised Manuscript Received on February 05, 2020.}

* Correspondence Author

M. Saravanan, Assistant Professor, Department of Mechanical Engineering, Vinayaka Mission's Kirupananda Variyar Engineering College, VinayakaMission's Research Foundation(Deemed to be University), Salem - 636 308, Tamilnadu, India. E-mail: msaravanan94@gmail.com

(c) The Authors. Published by Blue Eyes Intelligence Engineering and Sciences Publication (BEIESP). This is an open access article under the CC BY-NC-ND license (http://creativecommons.org/licenses/by-nc-nd/4.0/)

$$
\begin{array}{ll}
\mathrm{A} & =\mathrm{D} \times \mathrm{H}=1 \times 1=1 \mathrm{~m}^{2} \\
\mathrm{~V} & =\text { Wind speed in } \mathrm{m} / \mathrm{s}
\end{array}
$$

The angular velocity of a rotor is given by

$\Omega=\lambda . \mathrm{V} / \mathrm{R}$

Where $\lambda=$ Dimensionless factor called the tip speed ratio. $\lambda$ is a characteristic of each specific wind mill and for a savonius rotor $\lambda$ is typically around unity

$$
\mathrm{R} \quad=\text { Radius of the rotor }
$$

The output of a rotating body is obtained from the product of torque and angular speed.

$$
\begin{array}{ll}
\mathrm{P} & =\mathrm{M} * \omega \\
\mathrm{P} & =\text { Output in N-m/s }(1 \mathrm{~N} \cdot \mathrm{m} / \mathrm{s}=1 \mathrm{~W}) \\
\mathrm{M} & =\text { Torque in N-m } \\
\omega & =\text { Angular speed } / \mathrm{s}=2 \pi \mathrm{n} / 60 \\
\mathrm{n} & =\text { Rotational speed in rpm }=(60 \omega) / 2 \pi \\
\mathrm{M} & =60 \mathrm{P} / 2 \pi \mathrm{n}
\end{array}
$$

According to Betz's law [Albert Betz 1919], the maximum power that is possible to extract from a rotor is $P_{\max }=16 / 27 * 1 / 2 * \rho * A * v^{3}$

\section{METHODOLOGY}

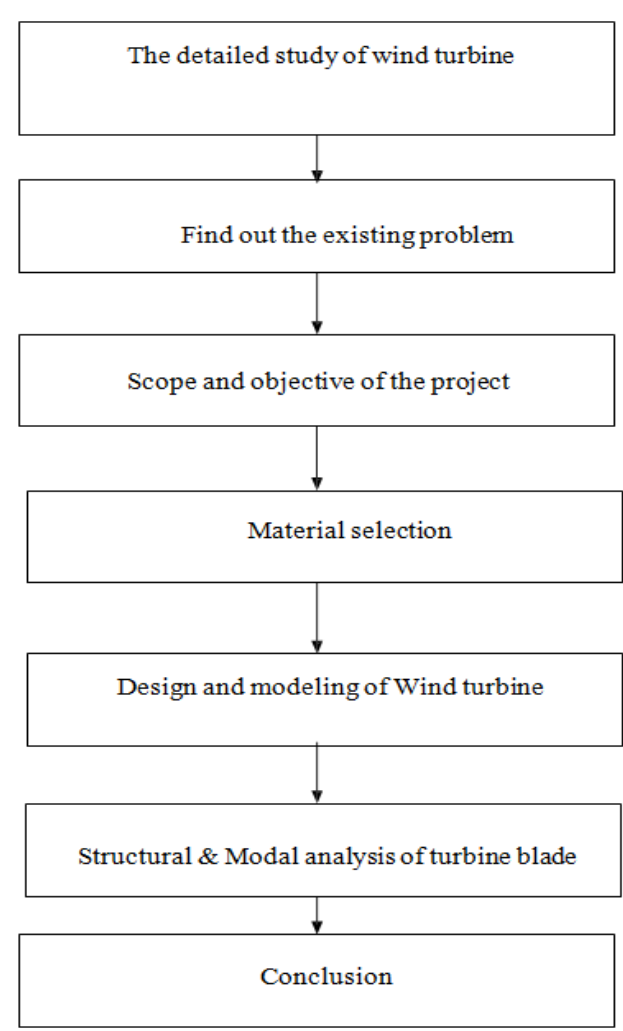

The savonius wind turbine made of Stainless Steel with one meter height and one meter diameter with four different shapes by changing arc radius of blade is designed by Solidworks software.

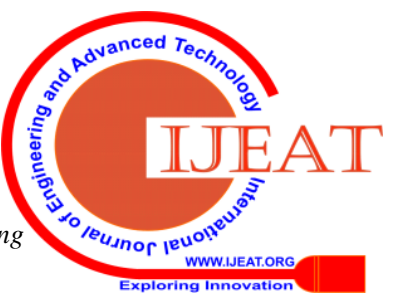




\section{Examination of Structural and Dynamic Properties for Vertical Axis Wind Turbine Blade Made of Stainless Steel using Ansys}

Then this design is exported to Ansys Workbench software for doing structural and modal analysis. Finally the results are tabulated and graphed for easy understanding.

Table 1 Power and Torque of the proposed wind turbine for various wind speeds

\begin{tabular}{|c|c|c|c|c|c|}
\hline $\begin{array}{c}\text { S. } \\
\text { No }\end{array}$ & $\begin{array}{c}\text { Wind } \\
\text { Speed } \\
(\mathbf{m} / \mathbf{s})\end{array}$ & $\begin{array}{c}\text { Angular } \\
\text { speed } \\
\text { (rad/sec) }\end{array}$ & $\begin{array}{c}\text { Rotational } \\
\text { Speed } \\
\text { (rpm) }\end{array}$ & $\begin{array}{c}\mathbf{P}_{\max } \\
\text { (watts) }\end{array}$ & $\begin{array}{c}\text { Torque } \\
\text { (n-m) }\end{array}$ \\
\hline 1 & 5 & 10 & 96 & 45.36 & 4.54 \\
\hline 2 & 6 & 12 & 115 & 78.38 & 6.53 \\
\hline 3 & 7 & 14 & 134 & 124.46 & 8.89 \\
\hline 4 & 8 & 16 & 153 & 185.78 & 11.61 \\
\hline 5 & 9 & 18 & 172 & 264.52 & 14.70 \\
\hline 6 & 10 & 20 & 191 & 362.85 & 18.14 \\
\hline 7 & 11 & 22 & 210 & 482.95 & 21.95 \\
\hline 8 & 12 & 24 & 229 & 627.00 & 26.13 \\
\hline 9 & 13 & 26 & 248 & 797.18 & 30.66 \\
\hline 10 & 14 & 28 & 267 & 995.66 & 35.56 \\
\hline 11 & 15 & 30 & 287 & 1224.62 & 40.82 \\
\hline
\end{tabular}

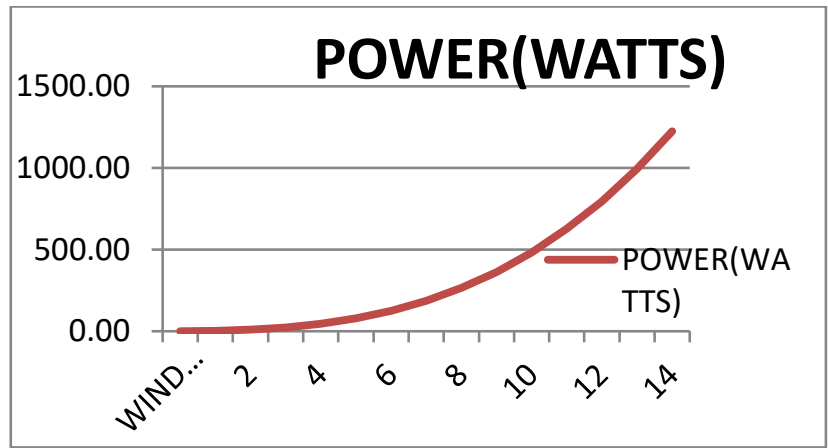

Figure 1 Wind Speed Vs Wind Power

\section{DESIGN OF SAVONIUS BLADE WITH FOUR DIFFERENT SHAPES}

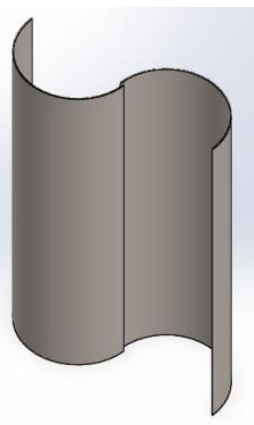

$\mathrm{R} 250 \mathrm{~mm}$

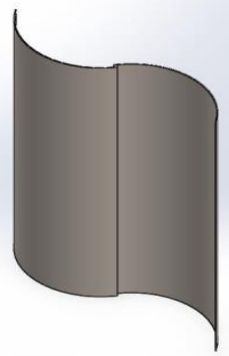

R350 mm

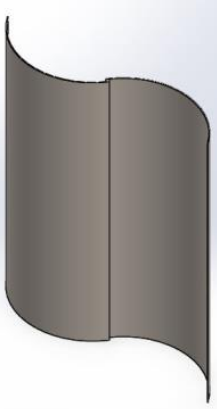

R300mm

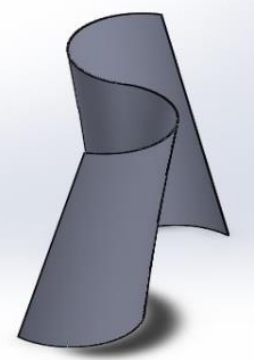

Twisted blade

Figure 2 Different shapes of Wind blades
Dimension: Height : 1000 mm, Rotor Diameter : 1000 mm, Thickness : $3 \mathrm{~mm}$

Each Blade has same chord length of $500 \mathrm{~mm}$ with different arc radius.

\section{STATIC STRUCTURAL ANALYSIS OF WIND BLADE}

All the four different shapes of stainless steel blades are analyzed with different loads of $500 \mathrm{~N}, 1000 \mathrm{~N}, 1500 \mathrm{~N}$ and $2000 \mathrm{~N}$. The results are tabulated and the comparisons of the results are plotted.

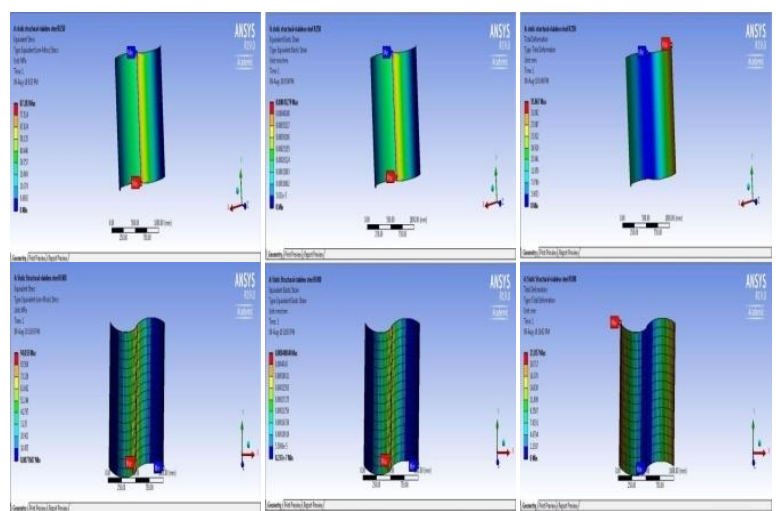

Figure 3 Stress, Strain and Total Deformation for R250 $\mathrm{mm}$ and $\mathrm{R} 300 \mathrm{~mm}$ in $500 \mathrm{~N}$ loads
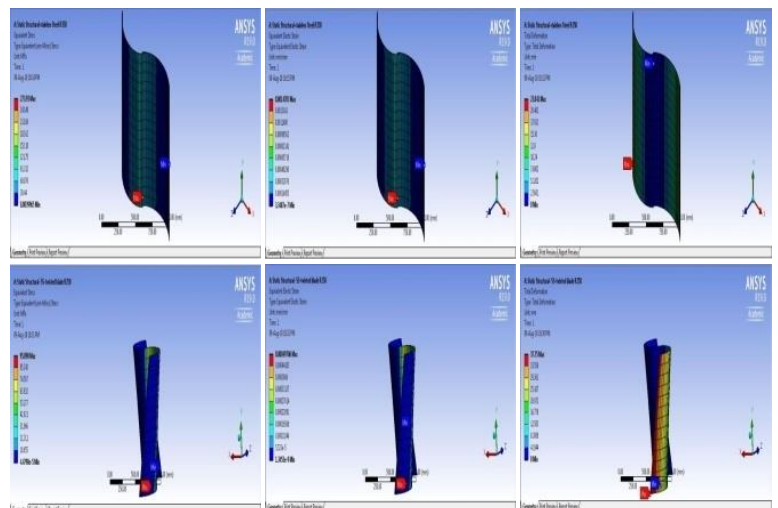

Figure 4 Stress, Strain and Total Deformation for R350 mm and Twisted with R250 mm in 500N loads

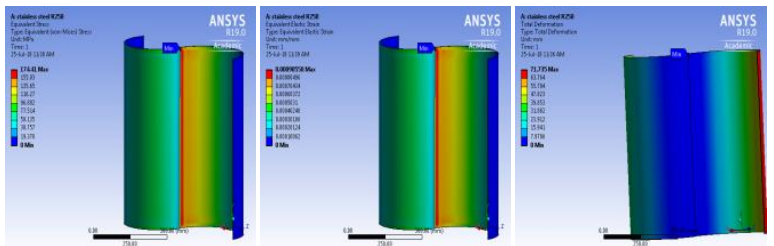




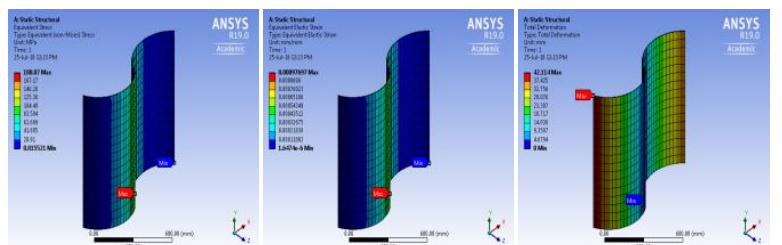

Figure 5 Stress, Strain and Total Deformation for R250 $\mathrm{mm}$ and $\mathrm{R} 300 \mathrm{~mm}$ in $1000 \mathrm{~N}$ loads

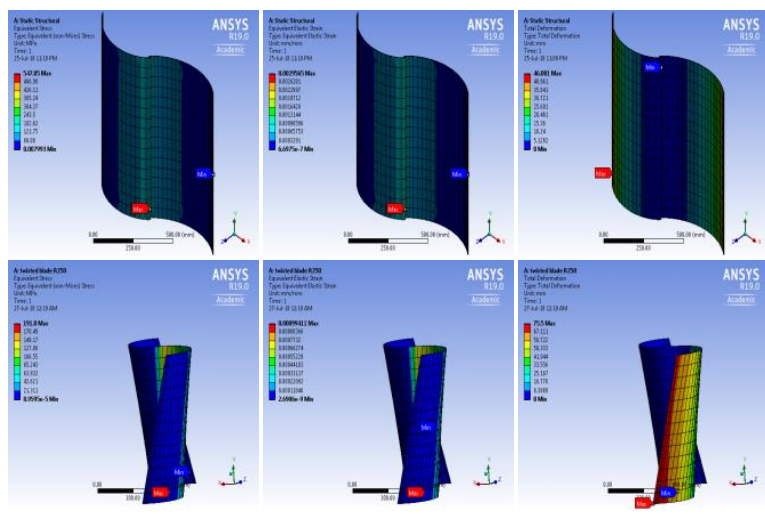

Figure 6 Stress, Strain and Total Deformation for R350 $\mathrm{mm}$ and Twisted with $\mathrm{R} 250 \mathrm{~mm}$ in $1000 \mathrm{~N}$ loads

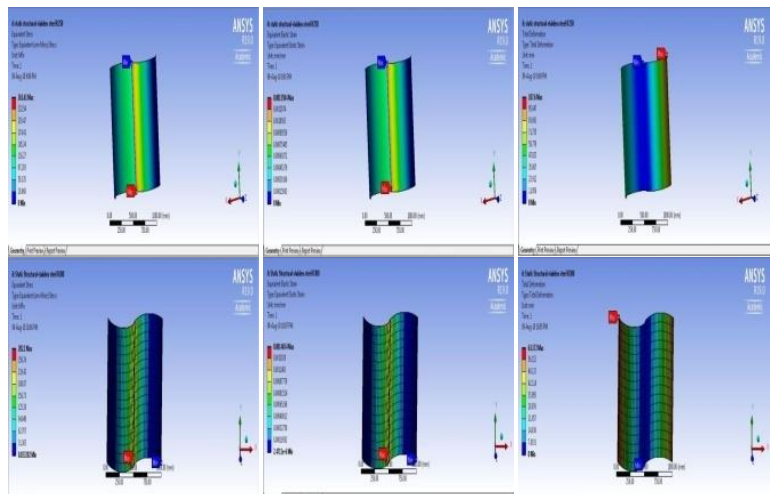

Figure 7 Stress, Strain and Total Deformation for R250 $\mathrm{mm}$ and $\mathrm{R} 300 \mathrm{~mm}$ in $1500 \mathrm{~N}$ loads
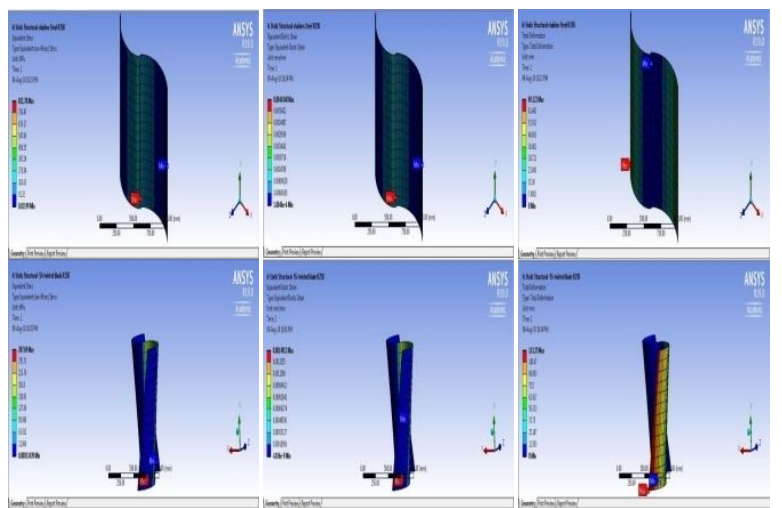

Figure 8 Stress, Strain and Total Deformation for R350 $\mathrm{mm}$ and Twisted with $\mathrm{R} 250 \mathrm{~mm}$ in $1500 \mathrm{~N}$ loads
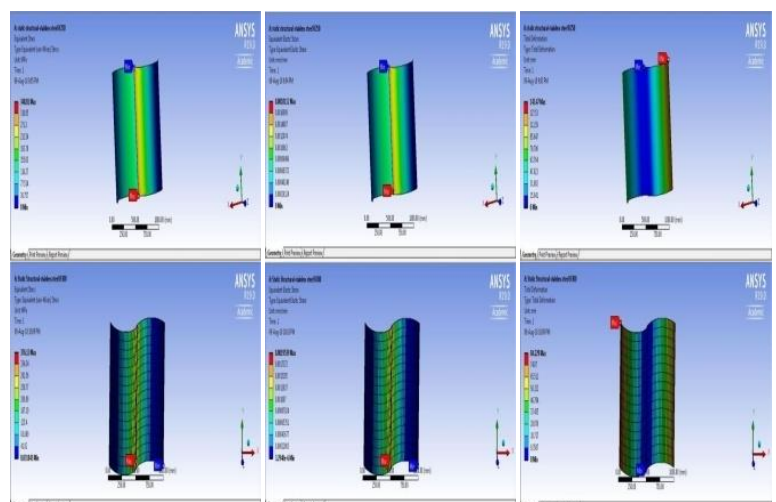

Figure 9 Stress, Strain and Total Deformation for R250 $\mathrm{mm}$ and $\mathrm{R} 300 \mathrm{~mm}$ in $2000 \mathrm{~N}$ loads
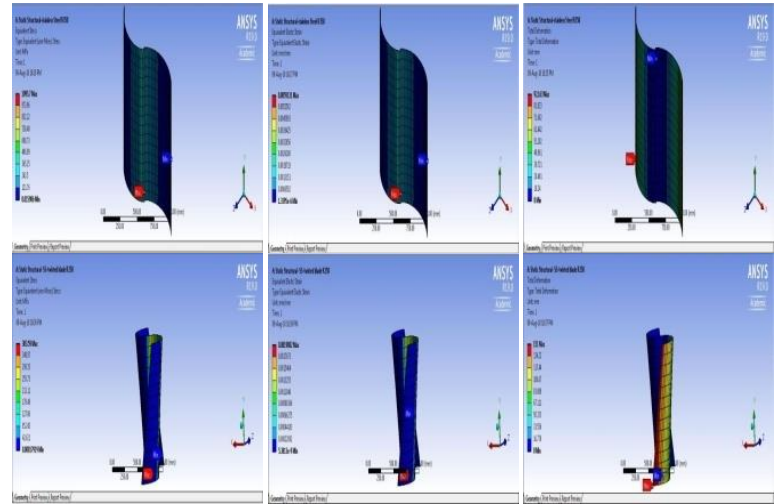

Figure 10 Stress, Strain and Total Deformation for R350 $\mathrm{mm}$ and Twisted with $\mathrm{R} 250 \mathrm{~mm}$ in $2000 \mathrm{~N}$ loads

\section{MODAL ANALYSIS OF WIND BLADE}

All the four different shapes of SS material blades are analyzed. The results are tabulated and the comparisons of the results are plotted.
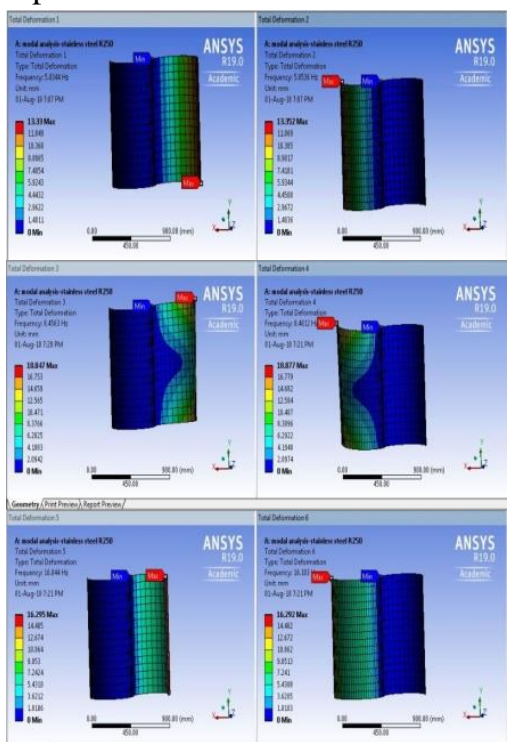

Figure 11 Natural Frequency and Total Deformation for R250 
Examination of Structural and Dynamic Properties for Vertical Axis Wind Turbine Blade Made of Stainless Steel using Ansys

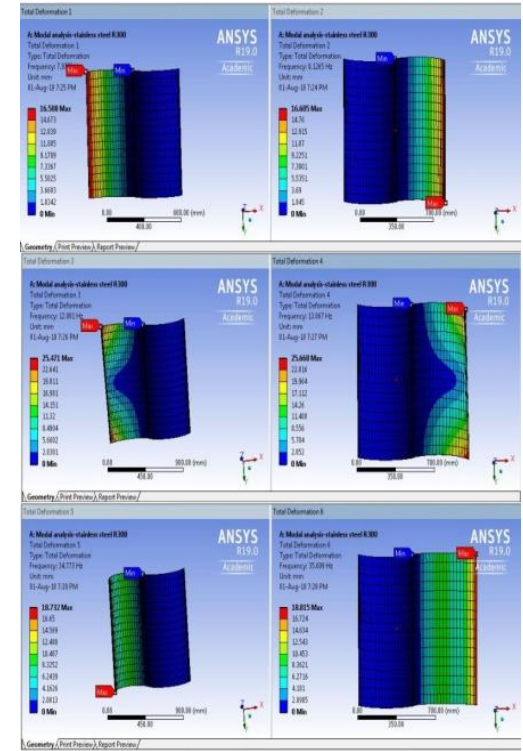

Figure 12 Natural Frequency and Total Deformation for R300

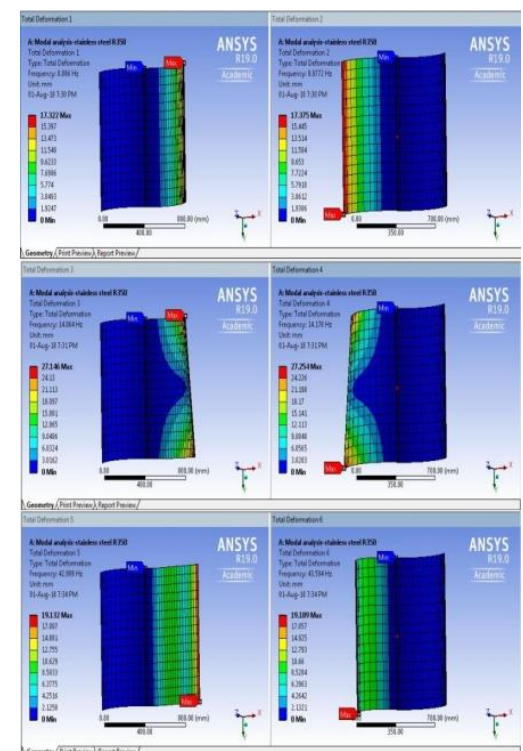

Figure 13 Natural Frequency and Total Deformation for R350

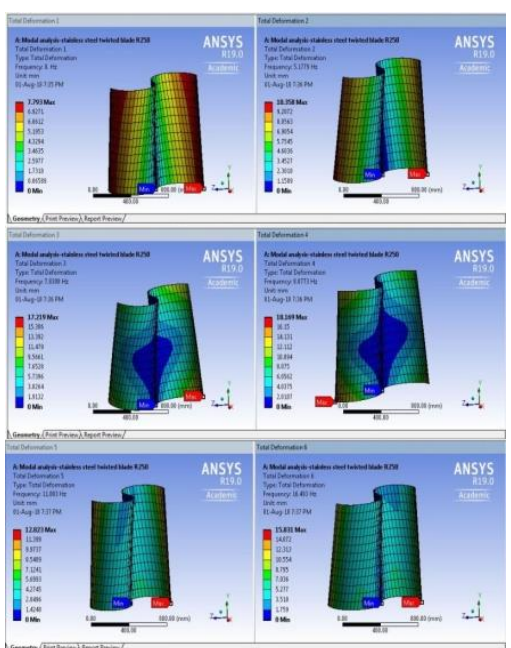

Figure 14 Natural Frequency and Total Deformation for Twisted blade

VII. RESULT AND DISCUSSION

Table 2 Load and Stess(MPa)

\begin{tabular}{|c|c|c|c|c|}
\hline $\begin{array}{c}\text { LOAD } \\
(\mathrm{N})\end{array}$ & SS R250 & SS R300 & SS R350 & $\begin{array}{c}\text { SS } \\
\text { TWISTED }\end{array}$ \\
\hline 500 & 87.203 & 94.033 & 273.93 & 95.898 \\
\hline 1000 & 174.41 & 188.07 & 547.85 & 191.8 \\
\hline 1500 & 261.61 & 282.1 & 821.78 & 287.69 \\
\hline 2000 & 348.81 & 376.13 & 1095.7 & 383.59 \\
\hline
\end{tabular}

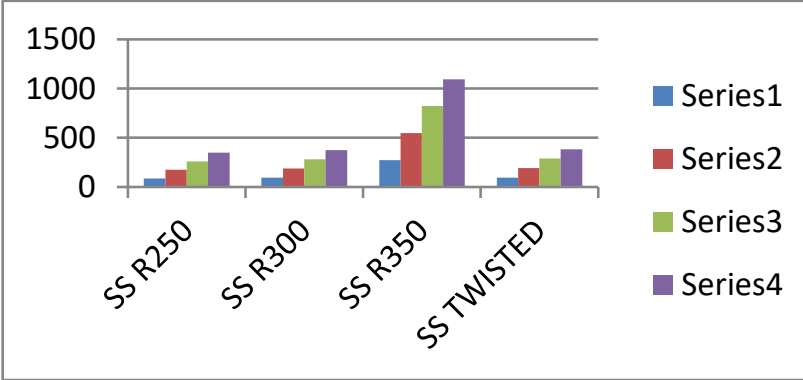

Figure 15 Load Vs Stress

Table 3 Load and Strain

\begin{tabular}{|c|c|c|c|c|}
\hline $\begin{array}{c}\text { Load } \\
(\mathrm{N})\end{array}$ & SS R250 & SS R300 & SS R350 & SS TWISTED \\
\hline 500 & 0.000452 & 0.0004884 & 0.001478 & 0.00049706 \\
\hline 1000 & 0.000905 & 0.0009769 & 0.002956 & 0.00099411 \\
\hline 1500 & 0.001358 & 0.0014654 & 0.004434 & 0.0014912 \\
\hline 2000 & 0.001811 & 0.0019539 & 0.005913 & 0.0019882 \\
\hline
\end{tabular}

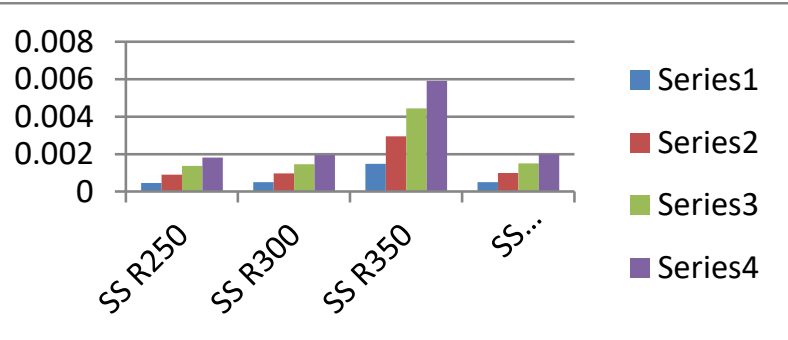

Figure 16 Load Vs Strain

Table 4 Load and Deformation (mm)

\begin{tabular}{|c|c|c|c|c|}
\hline $\begin{array}{c}\text { LOAD } \\
(\mathrm{N})\end{array}$ & SS R250 & SS R300 & SS R350 & $\begin{array}{c}\text { SS } \\
\text { TWISTED }\end{array}$ \\
\hline 500 & 35.867 & 21.057 & 23.041 & 37.75 \\
\hline 1000 & 71.735 & 42.114 & 46.081 & 75.5 \\
\hline 1500 & 107.6 & 63.172 & 69.122 & 113.25 \\
\hline 2000 & 143.47 & 84.229 & 92.163 & 151 \\
\hline
\end{tabular}

Published By:

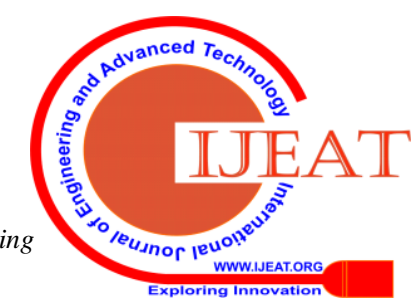




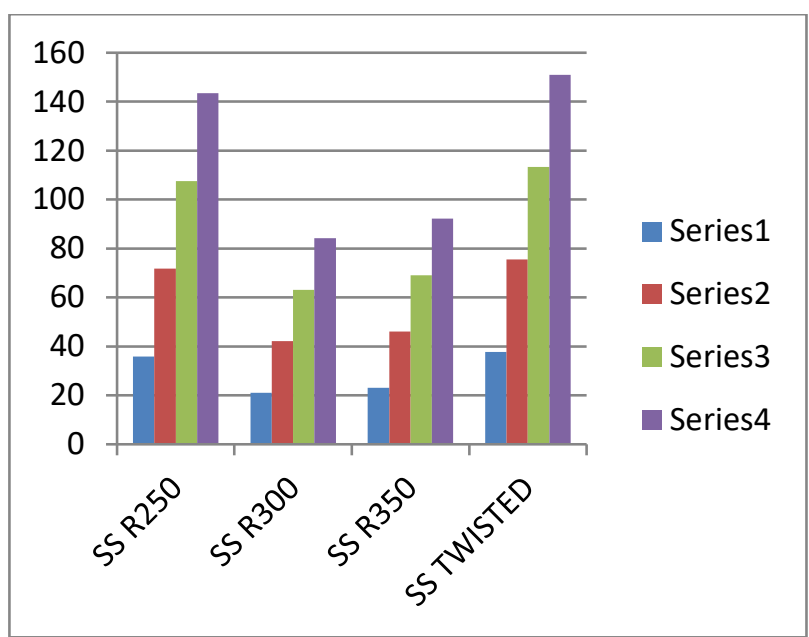

Figure 17 Load Vs Deformation

Table 5 Natural Frequency and Deformation

\begin{tabular}{|c|c|c|c|c|c|c|c|c|}
\hline \multirow[t]{2}{*}{$\begin{array}{c}\text { Mod } \\
\mathrm{e}\end{array}$} & \multicolumn{2}{|c|}{ SS R250 } & \multicolumn{2}{|c|}{ SS R300 } & \multicolumn{2}{|c|}{ SS R350 } & \multicolumn{2}{|c|}{$\begin{array}{c}\text { SS- Twisted } \\
\text { Blade }\end{array}$} \\
\hline & $\begin{array}{l}\text { Freq. } \\
(\mathrm{Hz})\end{array}$ & $\begin{array}{c}\text { Defo } \\
\mathrm{r} \\
\mathrm{mm}\end{array}$ & $\begin{array}{l}\text { Freq. } \\
(\mathrm{Hz})\end{array}$ & $\begin{array}{c}\text { Defo } \\
\mathrm{r} \\
\mathrm{mm}\end{array}$ & $\begin{array}{c}\text { Freq. } \\
\mathrm{Hz}\end{array}$ & $\begin{array}{c}\text { Defo } \\
\mathrm{r} \\
\mathrm{mm}\end{array}$ & $\begin{array}{c}\text { Freq } \\
\dot{\mathrm{Hz}} \\
\end{array}$ & $\begin{array}{c}\text { Defo } \\
\mathrm{r} \\
\mathrm{mm} \\
\end{array}$ \\
\hline 1 & $\begin{array}{c}5.03 \\
4\end{array}$ & 13.33 & $\begin{array}{c}7.93 \\
3\end{array}$ & 16.5 & 8.88 & 17.32 & 0.13 & 7.79 \\
\hline 2 & $\begin{array}{c}5.05 \\
3\end{array}$ & 13.35 & $\begin{array}{c}8.12 \\
6\end{array}$ & 16.6 & 8.97 & 17.37 & 5.17 & 10.35 \\
\hline 3 & $\begin{array}{c}8.45 \\
6\end{array}$ & 18.84 & $\begin{array}{c}12.8 \\
8\end{array}$ & 25.47 & $\begin{array}{c}14.0 \\
6\end{array}$ & 27.14 & 7.83 & 17.21 \\
\hline 4 & $\begin{array}{c}8.48 \\
1\end{array}$ & 18.87 & $\begin{array}{c}13.0 \\
6\end{array}$ & 25.66 & $\begin{array}{c}14.1 \\
7\end{array}$ & 27.25 & 8.87 & 18.16 \\
\hline 5 & $\begin{array}{c}16.0 \\
4\end{array}$ & 16.29 & $\begin{array}{c}34.7 \\
7\end{array}$ & 18.73 & $\begin{array}{c}42.9 \\
8\end{array}$ & 19.13 & 11.0 & 12.82 \\
\hline 6 & $\begin{array}{c}16.1 \\
0\end{array}$ & 16.29 & $\begin{array}{c}35.6 \\
0\end{array}$ & 18.81 & $\begin{array}{c}43.5 \\
9\end{array}$ & 19.18 & 16.5 & 15.83 \\
\hline
\end{tabular}

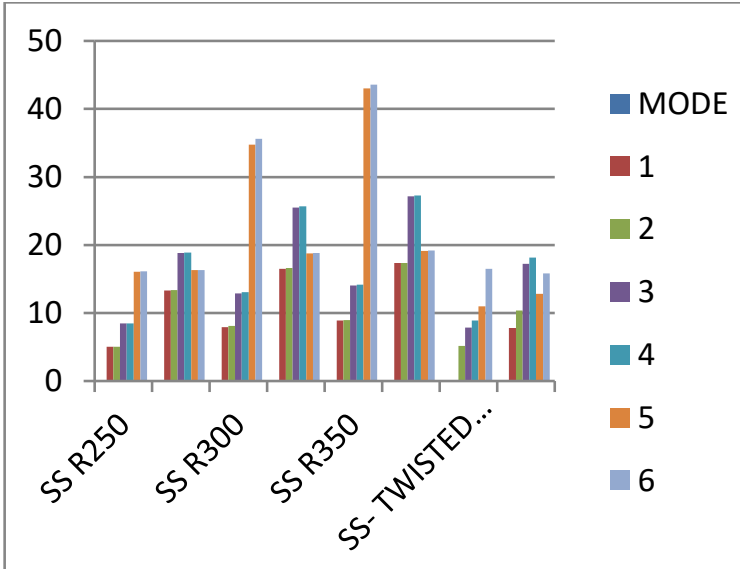

Figure 18 Natural Frequency And Deformation For Different Mode Shapes

Modal analysis is used to calculate the linear response of structures to dynamic loading. In modal analysis, we decompose the response of the structure into several vibration modes. A mode is defined by its frequency and shape. The mode is the shape of the vibration

\section{NATURAL FREQUENCIES AND MODE SHAPES}

Natural frequency is the frequency of the structure at which it tends to vibrate when it is disturbed. Mode shape is specific pattern of vibration of a structure to a specific frequency. Due to various rotational speed (RPM) of the rotor, we obtain various forcing frequency [Domenico Lombardi 2017] which has been tabulated.

Forcing Frequency $(\mathrm{Hz})=$ Rotational Speed in Revolution/Second

The natural frequency of the rotor should not be equal to forcing frequency. If both the frequency match, the structure of rotor is going to be resonate. This resonance will cause the increased amplitude of vibration and this increased amplitude may lead to the failure of structure.

\section{RESONANCE}

Resonance is the tendency of a system to oscillate with high amplitude when excited by energy at a certain frequency. This frequency is known as the system's natural frequency of vibration or resonant frequency. For a wind turbine, this means that the rotational speed during normal operations should never be the same as the natural frequency of its component The maximum stress of $1095.7 \mathrm{MPa}$ and strain of 0.0059131 is realized in SS R350 blades at $2000 \mathrm{~N}$ loads. In modal analysis the natural frequencies of different blades made of stainless steel at different wind speed were compared with forcing frequency and no natural frequencies match with forcing frequencies. So failure of structure will not occur.

\section{CONCLUSION}

The result of static structural analysis to evaluate displacement, stress and strain is good and result shows that Stainless Steel is better choice to fabricate wind turbine blades. Modal analysis result also shows that the failure of structure will not happen. After comparing the analysis result of all the four different shapes, it is decided that SS R350 mm blade is the better choice.

It is suitable for houses in urban areas to produce electricity. It is capable of producing electric power of 363 Watts and 1225 Watts at wind speed of $10 \mathrm{~m} / \mathrm{s}$ and $15 \mathrm{~m} / \mathrm{s}$ respectively.

\section{REFERENCES}

1. Asis Sarkar and Dhiren Kumar Behera, 2012, "Wind Turbine Blade Efficiency and Power Calculation with Electrical Analogy", International Journal of Science and Research Publications, Volume 2, Issue 2, ISSN 2250-3153.

2. B.Bittumon, Amith Raju, Harish Abraham Mammen, Abhy Thamby, Aby K Abraham, "Design and Analysis of Maglev Vertical Axis Wind Turbine", IJETAE, 2014.

3. Selvam.M, Ramesh.R, Palanisamy.R, Mohan.A and Muthumanokar.A, "Design and Analysis of Vertical Axis Wind Turbine", IJDR,2014.

4. Ashwin Dhote, Vaibhav Bankar, "Design, Analysis and Fabrication of Savonius Veritical Axis Wind Turbine”, IRJET, 2015

5. Hikkaduwa Vithanage, Ajith, "Design and Performance Analysis of Pitched-Plate Vertical Axis Wind Turbine for Domestic Power Generation", 2012.

6. M.Saravanan, Dr.K.G.Muthurajan, "Modal Analysis Of Savonius Vertical Axis Wind Turbine Blade Made Of Stainless Steel Material Using Ansys", International Journal of Mechanical and Industrial Technology, ISSN 2348-7593, Volume 6, Issue 2, Month: October 2018 - March 2019, pp. 20-24. 
Examination of Structural and Dynamic Properties for Vertical Axis Wind Turbine Blade Made of Stainless Steel using Ansys

7. M.Saravanan, Dr.K.G.Muthurajan, "Design And Structural Analysis Of Savonius VAWT Blades Made Of Stainless Steel", International Journal of Research and Analytical Reviews, E ISSN 2348-1269, Print ISSN 2349-5138, Volume 5, Issue 4, Oct. - Dec. 2018, pp. i996-i1000.

8. N.H.Mahmoud, A.A.El-Haroun, E.Wahba, M.H.Nasef, "An experimental study on improvement of Savonius rotor performance", Alexandria Engineering Journal(2012).

\section{AUTHORS PROFILE}

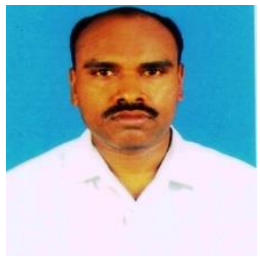

M.Saravanan, Assistant Professor, Department of Mechanical Engineering,, Vinayaka Mission's Kirupananda Variyar Engineering College, Vinayaka Mission's Research Foundation(Deemed to be University), Salem - 636 308, Tamilnadu, India. E-mail: msaravanan94@gmail.com. 